Kathmandu School of Law Review (KSLR),

Volume 8, Issue 1, 2020, pp 77-89

https:// doi.org/10.46985/kslr.v8i1.2129

(C) KSLR, 2020

\title{
Impact of COVID-19 on Healthcare in Humanitarian Settings
}

Kanak Mishra*

\begin{abstract}
Right to bealth is a human right available to everyone at all times. However, healthcare under International Humanitarian Law (IHL) is contingent on there being an 'armed conflict.' With the world healthcare institutions crumbling with COVID-19 and the worsening humanitarian crisis in many countries, the achievement of universal healthcare stands threatened to its core. In the absence of enough literature, this article attempts to bring out the challenges in the protection of health in complicated humanitarian settings, especially in light of the ongoing pandemic. It also seeks to emphasize that despite the existence of IHL through treaties and Customary International Law, there exists an inability to protect the healthcare professionals in areas of conflict. Further, it also attempts to delve deep into the challenges of access to and protection of public healthcare to the most vulnerable groups in humanitarian settings such as women, children, and refugees. The article concludes by stressing the need to pursue global solidarity to battle the pandemic through building trust and implementing approaches suitable to the needs of all the stakeholders in the humanitarian settings ranging from the perpetrator states, Non-State Armed Groups (NSAGs), civilians, military personnel, to the healthcare professionals involved in administering humanitarian aid.
\end{abstract}

\section{Introduction}

A report by the Global Humanitarian Review states that in 2020, approximately 168 million people will need humanitarian protection and assistance. ${ }^{1}$ The onslaught of COVID-19 pandemic has deeply compromised the existing healthcare system in underdeveloped and developed countries alike. The impact of COVID-19 in humanitarian settings is deeply threatening and warrants the urgent attention of the international community.

* Kanak Mishra is the Assistant Director of International Relations at O.P. Jindal Global University, India. She is associated as a senior peer-reviewer in reputed international and national law blogs and journals. She can be reached at muskan1403@gmail.com.

This paper was awarded the 3rd Best Paper in the International Research Paper Writing Competition, which was organized by Kathmandu School of Law Review, Amnesty International Fusion Youth Network, and the Cognition Club.

1 'Launch of the Global Humanitarian Overview 2020, OCHA', available at https://www.unocha.org/ global-humanitarian-overview-2020, accessed on 24 July 2020 
Initially, the right to health was a part of 'Article 25- adequate standard of living' of the Universal Declaration of Human Rights, 1948. It was however later recognized as a fullfledged human right under article 12 of the International Covenant on Economic, Social and Cultural Rights (ICESCR), $1966 .{ }^{2}$ General Comment 3 of the ICESCR states the right to primary healthcare as a non-derogable right with the due interpretation of a certain 'minimum core' obligations that the states need to fulfil along with basic education, food, water and sanitation. ${ }^{3}$ Article 2 (1) of the above-stated Covenant mandates the states towards a 'progressive realization' of basic human rights with the maximum available funds and resources. The idea behind progressive realization is to ensure that the states do not compromise on human rights with an excuse of unavailability or insufficiency of funds. ${ }^{4}$

World Health Organization (WHO) has continuously warned against the 'infodemic' of false and fabricated news that has the potential to do more harm than good right from the day; it declared COVID-19 as a global pandemic. ${ }^{5}$ Infodemic about COVID-19 has not just caused panic but has also profoundly stigmatized the disease. The stigmatization of COVID-19 has reverberated to a huge extent. Some countries have decided not to report the cases at all or to under-report the actual number of cases. Turkmenistan is one such country that has failed to report even a single case of COVID-19 till yet. ${ }^{6}$ Failure to report the international spread of diseases is unfamiliar and hence warrants the attention of international law, especially in the time of a pandemic that warrants urgent global solidarity.

Article 12 (right to health) of the ICESCR imposes a duty on the states to prevent, treat and control epidemic, endemic, occupational and other diseases. ${ }^{7}$ General Comment 14, in paragraph 40 , imposes a duty on the states to cooperate and report the diseases transmissible beyond the state borders, to the international community. ${ }^{8}$

Other than the right to health, the United Nations (UN) specialized agency WHO in 2005, came up with a set of legal rules that specially deal with the international spread of diseases. Article 3 of the International Health Regulations (2005), mandate the universal application and implementation of these regulations for the protection of people from

2 'Human Rights and Health', available at https://www.who.int/news-room/fact-sheets/detail/humanrights-and-health, accessed on 24 July 2020.

3 'General Comment 3' (ESCR-Net) available at https://www.escr-net.org/resources/general-comment-3, accessed on 24 July 2020.

4 Paul Hunt, 'Interpreting the International Right to Health in a Human Rights-Based Approach to Health,' Health and Human Rights, volume 109, 2016, p. 18.

5 Zoe Thomas, 'Misinformation on Coronavirus Causing "Infodemic" BBC Nens, 13 February 2020, available at https://www.bbc.com/news/technology-51497800, accessed on 24 July 2020.

6 'Explained: The Strange Case of Turkmenistan, the Country with "No COVID-19 Cases", The Indian Express, 12 July 2020, available at https://indianexpress.com/article/explained/turkmenistan-coronaviruscases-explained-6497242/, accessed on 24 July 2020.

'OHCHR, International Covenant on Economic, Social and Cultural Rights' available at https://www. ohchr.org/EN/ProfessionalInterest/Pages/CESCR.aspx, accessed on 27 July 2020.

8 'General Comment No. 14 (2000), The Right to the Highest Attainable Standard of Health (Article 12 of the International Covenant on Economic, Social and Cultural Rights)' available at https://digitallibrary. un.org/record/425041?ln=en, accessed on 24 July 2020. 
the international spread of diseases. The regulation binds 196 member countries of the WHO to work in coherence to detect, assess and report the public health events by establishing a dedicated health unit in international border crossings, ports, airports etc. ${ }^{9}$

Understanding the interplay of both the above stated international covenants, i.e. International Human Rights and the International Health Regulations (2005) is interesting because of two reasons. Firstly, because the intersection of both covenants attracts the much larger debate based on the touchstone of international law being a 'soft law.' Secondly, both the covenants raise the issue of legally binding rights and obligations of the states to 'cooperate' and 'report' the diseases.

The duty to cooperate is recognized as customary international law, but ironically it is also said to be one of the core UN objectives rather than a binding legal obligation. ${ }^{10}$ However, even if the interpretation of the duty of states to cooperate is borrowed from the ICESCR Article 2 (1), the legally binding character to make the states answerable to the international community cannot be guaranteed. Therefore, the risk of states not reporting or cooperating stands in consonance with all the other rights based on the principle of progressive realization enshrined in international covenants such as ICESCR, that ultimately depend on the extent of states' commitments to such covenants. ${ }^{11}$ Thus, it can be said that all the states, be it at war or in peace have an international obligation to cooperate and report COVID-19 cases in their respective countries. Yet, the enforcement of human rights law stands as a significant and continuing challengethereby giving international law 'soft' law underpinnings.

The fallibility of human rights law gets exacerbated in humanitarian settings, especially those involving Non-State armed groups (NSAGs). Despite there being a right to health for all be it in war or peace, it becomes tough to ensure access to healthcare in countries like Syria, Yemen, Sudan, Democratic Republic of Congo (DRC) that are battling complex conflicts from many years. Humanitarian response in conflict-ridden areas often lacks commitment to the protection of healthcare.

\section{International Human Rights Law (IHRL) and International Humanitarian Law (IHL) on Health}

As has been discussed in the section above, human rights apply in both war and peacetime unless the states derogate some rights. Derogation under Article 4 of the International Covenant on Civil and Political Rights (ICCPR) can be permissible only under emergencies 'which threaten the life of a nation'. ${ }^{12}$ Such derogations are subject to annual review by

\footnotetext{
9 'WHO, About IHR' (WHO) available at http://www.who.int/ihr/about/en/, accessed on 24 July 2020.

10 Olha Bozhenko, 'More on Public International Law and Infectious Diseases: Foundations of the Obligation to Report Epidemic Outbreaks', EJIL: Talk!, 15 August 2019, available at https://www.ejiltalk. $\mathrm{org} /$ more-on-public-international-law-and-infectious-diseases-foundations-of-the-obligation-to-reportepidemic-outbreaks/, accessed on 24 July 2020.

11 Ibid.

12 'OHCHR, International Covenant on Civil and Political Rights', available at https://www.ohchr.org/en/
} 
the Sub-Commission on Prevention of Discrimination and Protection of Minorities. ${ }^{13}$

Although IHL provides key framework for the law in conflict settings, it also comes to the rescue during health emergencies such as pandemic. ${ }^{14}$ Be it for medical personnel, facilities and transport, water, humanitarian relief detainees, internally displaced persons, migrants, asylum seekers and refugees, protected persons, children and persons specifically at risk such as those with compromised immune systems like old people in case of COVID-19.

The painful reality and truth of the hostility in the battle of Solferino made Henry Dunant imagine an impartial body that could take care of people affected by the war, which he mentions in his book titled 'Un Souvenir de Solférino'. ${ }^{15}$ Much later in the year 1864, came up the four Geneva Conventions or (the War Convention) that seek to protect the sick and wounded in the war. The First Geneva Convention of 1864 sought to protect the soldiers of the war and medical professionals, the Second Convention of 1907 extended the former to protect victims of sea wars, the Third Convention of 1929 dealt with the humane treatment of prisoners of war and the Fourth Geneva Convention of 1949 extended the prior conventions to the protection of civilians during armed conflicts. ${ }^{16}$ Geneva Conventions, established under the tutelage of the International Committee of the Red Cross (ICRC), therefore established IHL as treaty law.

IHL however, also derives its principles from the rules of Customary International Law. The idea behind recognizing IHL as customary law was the need to protect and act in aid of the victims of war who did not engage in any combat. ${ }^{17}$ These customary rules were also influenced by religious ideas to prohibit cruel and inhumane behavior of sitting back and watching innocent people die.

\section{Healthcare under International Humanitarian Law (IHL)}

This section shall focus on the scope of IHL or the law of armed conflicts, to the extent that it deals with healthcare services. It will also discuss who all are the beneficiaries of healthcare services under IHL.

The academic engagement on the scope of healthcare under IHL is comparatively limited as compared to the discussion of healthcare under IHRL. The author believes that in today's dynamic and changing global order, it is essential for the general masses

professionalinterest/pages/ccpr.aspx, accessed on 25 July 2020.

13 'OHCHR, SC Sub-Commission on the Promotion and Protection of Human Rights', available at https:// www.ohchr.org/EN/HRBodies/SC/Pages/SubCommission.aspx, accessed on 25 July 2020.

14 COVID-19: How IHL provides crucial safeguards during pandemics, 2020, https://www.icrc.org/en/ document/covid-19-how-ihl-provides-crucial-safeguards-during-pandemics, accessed on 8 January 2021.

15 Abdulaziz Omar, 'Understanding and Preventing Attacks on Health Facilities During Armed Conflict in Syria,' Risk Management and Healthcare Policy, 2020.

16 Ibid.

17 'Customary International Humanitarian Law', available at https://www.icrc.org/en/document/customaryinternational-humanitarian-law-0, accessed on 25 July 2020. 
to be aware of the humanitarian law which seems to be gaining momentum in light of the recent international happenings.

IHL ensures that the wounded and the sick are provided adequate medical care at the earliest opportunity without any discrimination. ${ }^{18} \mathrm{IHL}$ also ensures the prohibition of cruel treatment by the denial of healthcare to the wounded and sick. Any further infliction of injuries to the bodies of the wounded and sick or the healthcare professionals would amount to 'war crimes. ${ }^{19}$

Article 56 of the Fourth Geneva Convention mandates the States to direct their available resources towards ensuring the fulfilment of the right to health for all. ${ }^{20}$ Similarly, IHL mandates the states to ensure proper healthcare infrastructure, while maintaining public health and hygiene to prevent the spread of contagious diseases and epidemics, in their best possible financial capacity. ${ }^{21}$ It is interesting to note that under both IHRL and IHL, the states cannot give excuses for the failure of their international healthcare obligations by citing their lack of financial resources. IHL provides that even in the case of limited financial resources, the states should direct their focus towards adopting "low-cost programs that target the most disadvantaged and marginalized members of the population." 22

Humanitarian law has evolved over-time to include many rules guarding 'healthcare.' Yet the conflict settings in some areas make it extremely difficult for the international community to check if the concerned states are fulfilling their obligations under both human rights law, as well as the humanitarian law.

It is essential to identify the politics that impede the access of humanitarian aid in areas of conflict. The post-conflict periods are usually the ones that reveal the destruction caused to the healthcare system by the perpetrators primarily through political attacks on hospitals, personal attacks on humanitarian aid workers and restricting the access to any aid. While the presence of adequate trained medical professionals in areas of conflicts is hard in itself, holding perpetrator states or NSAGs accountable for the targeted attacks against such healthcare workers and the inability of the international community to protect these workers is one of the most challenging tasks. It is also challenging to establish coordination between the relevant international bodies like the $\mathrm{UN}$, the states engaged in the conflict, NSAGs (if any) and the international community. Coordination efforts during serious conflicts have to tread effectively for there to be actual healthcare work measurable through concrete numbers.

\footnotetext{
18 'Respecting and Protecting Health Care in Armed Conflicts and in Situations Not Covered by International Humanitarian Law - Factsheet', International Committee of the Red Cross, 15 September 2014, available at https://www.icrc.org/en/document/respecting-and-protecting-health-care-armed-conflicts-andsituations-not-covered, accessed on 25 July 2020.

19 Tadić Case, Prosecutor v. Tadić, ICTY, Decision on Defense Motion for Interlocutory Appeal on Jurisdiction, 1995, Case no. IT-94-I, paras. 86-136.

20 See Geneva Convention Relative to the Protection of Civilian Persons in Time of War (Fourth Geneva Convention), 12 August 1949, 75 UNTS 287, art. 56.

21 Ibid.

22 Ibid.
} 
The reasons for the denial of protection or the targeted attacks on the healthcare professionals have remained constant over the years despite there being a complete body of international law (IHL) devoted to understanding and addressing such issues. ${ }^{23}$ Repetitive attacks on healthcare professionals helping in humanitarian aid should make us question the development of IHL (if at all) to ensure the protection and effective working of medical professionals. On an aspect as personal as healthcare, the understanding of perpetrator discourse in humanitarian law is significant.

The author borrows from the example of $\mathrm{Nigeria}^{24}$ to build upon the narrative of perpetrator discourse for the global south in general. In the Nigerian civil war, Nigeria wanted to keep 'the rest of the world out' and hence denied any interventions from the International Committee of the Red Cross (ICRC). Much like Nigeria, many countries from the global south wish that the global north would not interfere in their domestic matters. Leaving aside the discussion on how problematic their domestic dispute might be, it is worth considering that such in the absence of trust and proper coordination mechanisms, the nametag of a perpetrator would indeed fall upon the agencies of humanitarian aid from the eyes of the state involved in the conflict. Thus, for Nigeria, the perpetrator was the ICRC, while for the ICRC, it was Nigeria.

The example above is extremely crucial to understand perpetrator discourse and most importantly, to understand who labels someone a perpetrator and why. In light of the North-South gap, it is essential to have suitable and targeted humanitarian healthcare approaches for the so-called global south. In the absence of appropriate methods of coordination in delivering healthcare, humanitarian law would become a means to demean and further endanger the lives of the people of the third world. ${ }^{25}$

\section{The COVID-19 pandemic}

The WHO declared the outbreak of COVID-19 as a 'pandemic' on the 11th of March 2020. ${ }^{26}$ At present, more than 188 countries have reported COVID-19 cases. $^{27}$ This unprecedented pandemic poses a considerable challenge to deliver emergency healthcare in humanitarian settings. The novel respiratory virus (SARS-CoV-2) has exacerbated the miserable plight of many countries such as Yemen, Syria and DRC struggling with complex humanitarian crisis. These countries lack basic infrastructure, including health services, hospitals, dispensaries, trained medical professionals etc. Apart from these, the

\footnotetext{
23 Duncan McLean, 'Medical Care in Armed Conflict: Perpetrator Discourse in Historical Perspective,' International Review of the Red Cross 771, 2019, p. 101 available at https://www.cambridge.org/core/product/ identifier/S1816383120000016/type/journal_article, accessed on 23 July 2020.

24 Ibid.

25 Obiora C Okafor, 'Newness, Imperialism, and International Legal Reform in Our Time: A Twail Perspective,' Social Science Research Network. 2005, SSRN Scholarly Paper ID 1572430.

26 'Coronavirus (COVID-19) Events as They Happen' available at https://www.who.int/emergencies/ diseases/novel-coronavirus-2019/events-as-they-happen, accessed on 26 July 2020.

27 'Coronavirus: Which Countries Have Confirmed Cases?|News |Al Jazeera' < https://www.aljazeera. com/news/2020/01/countries-confirmed-cases-coronavirus-200125070959786.html, accessed on 24 July 2020 .
} 
ongoing violence, poor political conditions and public distrust also add to the reasons why international aid and interventions do not reach the desired ends.

Access to healthcare involves the following five dimensions- 'availability, accessibility, accommodation, affordability and acceptability. ${ }^{28}$ The ongoing pandemic has made the achievement of all the five aspects more challenging than ever, especially in the conflict-ridden areas battling inadequate security, life threatening-violence, emergency healthcare and lack of funding. It is common knowledge that the international advisories, including those given by the WHO are all centered on the WASH tools of water, sanitation and hygiene tools.

However, the health systems in the global south are often poorly resourced, suffer from shortages of healthcare workforce, lack adequate WASH tools and consequently routine infection control practices. ${ }^{29}$ Conflict ridden areas also battle systemic poverty, malnutrition and hunger, political crisis and overarching violence, along with increased floods and famines due to climate change are thereby making hygiene, sanitation and social distancing rules extremely challenging to implement. Thus, COVID-19 would indeed have disastrous effects in humanitarian settings.

The focus of humanitarian organizations, including the International Committee of the Red Cross and other international organizations or NGO's has always been on training healthcare professionals for the poorly resourced areas. Most conflict settings are impoverished countries with minimal or no resources, so it makes sense to train the healthcare professionals to work with the existing medical infrastructure or employ indigenous aid organizations. ${ }^{30}$

However, in times of COVID-19, there is a pressing need for a complete overhaul of the current healthcare system to be more professional. There should be a mindful and swift overhaul of the healthcare system to enable professionally nuanced healthcare remotely. To achieve the same, humanitarian organizations should take up specific approaches to healthcare that are not just structured professionally but can also be delivered through indigenous NGOs or organizations. Multidisciplinary approaches to healthcare imbibing disciplines such as sciences, social sciences, law, health, economics and diplomacy can act well in aiding indigenous organizations. ${ }^{31}$

\section{Vulnerable groups amongst the most affected by COVID-19}

IHL has had a perpetual struggle in dealing with the attacks on humanitarian workers. The problems on attacks on humanitarian workers are much complex than they

28 Dilshad Jaff, Sheila Leatherman \& Linda Tawfik, 'Improving Quality of Care in Conflict Settings: Access and Infrastructure Are Fundamental,' International Journal for Quality in Health Care G187, 2019, p. 31.

29 Lucy Singh et al., 'What Does "Leave No One behind” Mean for Humanitarian Crises-Affected Populations in the COVID-19 Pandemic?' BMJ Global Health, 2020, p. 5.

30 Elin A Gursky et al., 'The Changing Face of Crises and Aid in the Asia-Pacific,' Biosecurity and Bioterrorism: Biodefense Strategy, Practice, and Science, volume 310, 2014, p. 12.

31 Ibid. 
seem. Even if the international community knows the perpetrator in terms of their accountability towards the attack, it is not always possible to punish them, especially if the perpetrators are NSAGs. Attacks on humanitarian workers can more than double up in pandemic because of the stigma attached to the spread of COVID-19. ${ }^{32}$

With gender-based violence on the rise around the globe, ${ }^{33}$ these attacks can easily materialize as targeted violence against the vulnerable groups such as women and girls, children and the marginalized sections of the population including migrants, asylum seekers and refugees. Such displaced persons are not just exposed to greater violence and atrocities but also to health and hygiene related outbreaks. Handling pandemic outbreaks in refugee camps with harsh living conditions and ongoing armed hostilities is an added obstacle to achieving peace and stability. ${ }^{34}$

In order to mitigate the crisis for the most vulnerable sections, there is a need for targeted and focused strategies that must include refugees at the international, national and local levels. ${ }^{35}$ The lives of refugees in countries like Syria, Afghanistan, South Sudan, Myanmar etc. are mostly torn apart in borders, documents and displacement, therefore, it is imperative to ensure that they get added assistance without having to undergo legal suspicions.

The plight of migrant workers in India, a third world country, is indeed an apt example of acute humanitarian and healthcare crisis. ${ }^{36}$ Lakhs of migrant workers, including women and children, were seen walking on the roads for thousands of miles when the Indian government declared an unannounced lockdown. The condition is much worse in Kashmir that witnesses complete internet shutdowns nearly every alternate day, ${ }^{37}$ thereby blocking any scope of accessing remote healthcare too. Women residing in rural areas are not able to access sexual and reproductive services, especially abortions, sometimes leading to miscarriages and unsafe abortions.

\section{Two-fold crisis: The Gendered Impact of COVID-19 in humanitarian settings}

The UN Secretary-General's policy brief states that the impact of COVID-19 on

32 'COVID-19 Impact on Humanitarian Operations', ACAPS, 8 April 2020, available at https://www.acaps. $\mathrm{org} /$ special-report/covid-19-impact-humanitarian-operations, accessed on 26 July 2020.

33 Lucy Bloxham, "The Shadow Pandemic: Gender Based Violence and COVID-19", Concern Worldwide, UK, available at https://www.concern.org.uk/news/shadow-pandemic-gender-based-violence-andcovid-19, accessed on 24 July 2020.

34 COVID-19: How IHL provides crucial safeguards during pandemics (n 14).

35 Singh et al. (n 27).

36 Chittaranjan Andrade, 'COVID-19: Humanitarian and Health Care Crisis in a Third World Country,' The Journal of Clinical Psychiatry, 2020, p. 81.

37 Niha Masih et al., "India's Internet Shutdown in Kashmir is the longest ever in a Democracy," The Washington Post, Asia \& Pacific, accessed on 16 December 2019, available at https://www. washingtonpost.com/world/asia_pacific/indias-internet-shutdown-in-kashmir-is-now-the-longest-everin-a-democracy/2019/12/15/bb0693ea-1dfc-11ea-977a-15a6710ed6da_story.html, accessed on 24 July 2020. 
women and girls is much worse than that on men. ${ }^{38}$ The policy brief lays down in bullet points the various facets of the lives of women and girls, where their sufferings multiply solely because of their sex. Women and girls engage in unpaid care work daily, which has only doubled in this pandemic when all the family members are staying in during the state-imposed lockdowns.

The state of sexual and reproductive healthcare is in shambles in many countries such as India where the problem is not just access to healthcare but also the lack of medical professionals specialized in fields such as abortion. Home is not necessarily a safespace for many. Gender-based violence is also on the rise because women and girls have to coexist with their abusers at home. ${ }^{39}$ The situation is even worse for women who do not have shelter in these testing times. With no long-term or also short-term support in terms of housing, sanitation, livelihood and food, poor women are at the mercy of the pandemic.

Often the health of women humanitarian- frontline workers get ignored at the behest of aiding the civilians. The ignorance or willful abstinence to engage in discussions on the protection of women frontline workers stems from the gender-imbalance at the leadership positions in humanitarian organizations and workforces. ${ }^{40}$ Women humanitarians are not just at a higher risk of COVID-19 infections, but their protection in cases of infection is also contingent upon organization-specific policies and procedures. ${ }^{41} \mathrm{It}$ is no wonder that the design of the PPE kits does not take into account the menstrual problems of women. Women doctors and nurses have increasingly complained about discomfort in PPE kits during their menstruation. ${ }^{42}$ The working conditions of essential women workers in humanitarian settings is only worse during COVID-19, which further exacerbates the plight of the already crumbling healthcare system.

The latest study by Lancet Global Health ${ }^{43}$ points out ample evidence that the discontinuation of healthcare for women and girls has contributed to more deaths than the public health emergencies itself. The lack of access to sexual and reproductive healthcare, including unsafe abortions and the neglect of rape survivors and HIV patients has the potential to outweigh COVID-19 fatalities.

38 'UN Secretary-General's Policy Brief: The Impact of COVID-19 on Women | Digital Library: Publications', UN Women, available at https://www.unwomen.org/en/digital-library/publications/2020/04/policybrief-the-impact-of-covid-19-on-women, accessed on 26 July 2020.

39 UNHCR - Gender-based violence on the rise during lockdowns, https://www.unhcr.org/news/ stories/2020/11/5fbd2e774/gender-based-violence-rise-during-lockdowns.html, accessed on 8 January 2021.

40 Vandana Sharma et al., 'Prioritizing Vulnerable Populations and Women on the Frontlines: COVID-19 in Humanitarian Contexts,' International Journal for Equity in Health, 2020 p. 19.

41 Ibid.

42 'Deployed on COVID-19 Duty, Women Doctors and Nurses in PPE Kit Bear Extreme Discomfort during Menstruation - Health News, Firstpost', available at https: / /www.firstpost.com/health/deployed-on-covid19-duty-women-doctors-and-nurses-in-ppe-kit-bear-extreme-discomfort-during-menstruation-8545011. html, accessed on 26 July 2020.

43 Not a Luxury: A Call to Maintain Sexual and Reproductive Health in Humanitarian and Fragile Settings during the COVID-19 Pandemic- Clinical Key', available at https://www-clinicalkey-com.ezproxy.library. tufts.edu/\#!/content/playContent/1-s2.0-S2214109X2030190X?returnurl=null\&referrer=null, accessed on 23 July 2020. 


\section{Steps to battle COVID-19}

To battle COVID-19, the international community needs to act in solidarity. There is a need to facilitate increased interaction amongst states and non-state actors, humanitarian organizations and the WHO through diplomatic and intellectual efforts to ensure the enforcement of Articles 2 and 56 of the IHL and other human rights under IHRL. ${ }^{44}$ Increased efforts of coordination between WHO and Taliban have worked out successfully, which is why WHO has successfully engaged in humanitarian aid in Afghanistan. ${ }^{45}$

For providing humanitarian relief, the humanitarian organizations must harbor the trust of the parties involved in the conflict and the civilians that are the victims of such conflict. This step could act as a milestone in increasing coordination between all the parties involved (including NSAGs) and could prove out to be monumental in slowing down the pace of COVID-19 infections.

The humanitarian approaches towards the eradication of COVID-19 need to be sensitive to the predicament of the global south and should be mindful of the mainstream capitalistic solutions. For it to happen, it is essential to amplify the voices of those who have lived and worked in humanitarian settings as a step towards comprehensive firsthand decision making. Since much of the humanitarian assistance during COVID-19 is going to be done remotely over the internet, it would be an extremely tough task. The evidence available for conducting humanitarian operations is limited, and hence, it is imperative to build more capacity for monitoring and doing frequent internet communications. ${ }^{46}$

The idea is to implement a decision-making approach that is centered on enabling infrastructural access to the existing healthcare systems or in the absence of the same, ensuring the ease of technology-based remote access by trained and experienced humanitarian workers. ${ }^{47}$

The latest study by Lancet Global Health ${ }^{48}$ suggests a four-pronged approach to mitigate the effects of COVID-19 on the mortality and morbidity rates due to sexual and reproductive health of people in humanitarian settings. First, all the essential healthcare services as defined under the Minimum Initial Services Package for sexual and reproductive health should continue. Second, sexual and reproductive health services should continue until the existing healthcare system gets overburdened with COVID-19 cases, post which sexual and reproductive healthcare should be imparted remotely through various technologies.

\footnotetext{
44 'COVID-19 Symposium: COVID-19 in Conflict-Affected Areas-Armed Groups as Part of a Global Solution', Opinio Juris, 4 April 2020, available at http:/ /opiniojuris.org/2020/04/04/covid-19-symposiumcovid-19-in-conflict-affected-areas-armed-groups-as-part-of-a-global-solution/, accessed on 25 July 2020.

45 Ibid.

46 Simran Chaudhri et al., 'Humanitarian Health Programming and Monitoring in Inaccessible Conflict Settings: A Literature Review,' Journal of International Humanitarian Action, volume 9, 2019, p. 4.

47 Jaff, Leatherman \& Tawfik (n 26).

48 Not a Luxury: A Call to Maintain Sexual and Reproductive Health in Humanitarian and Fragile Settings during the COVID-19 Pandemic- ClinicalKey' (n 36).
} 
Third, unambiguous and updated information regarding the type of healthcare should be made available to the people at the earliest. Fourth, COVID-19 patients, as well as the COVID-19 healthcare professionals, should be supplied with adequate precautionary measures such as PPE kits, soaps and hand sanitizers.

\section{UN Report on COVID-19}

The UN Report on COVID-19 (April 2020) $\underline{49}$ invites the attention of all towards humanitarian law. The report states that IHL seeks to protect the most vulnerable in crisis by ensuring unrestricted access of humanitarian aid by deploying trained healthcare professionals and supplying adequate personal protective equipment (PPEs) and medicines in complex situations of armed-conflicts. The report urges the parties to the conflict explicitly to not fuel the crisis by heightening the pre-existing difficulty of 'refugees and other vulnerable groups' in accessing healthcare. The report emphasizes that it is oppressed and marginalized that are facing the brunt of this pandemic the most. Hence, these groups are the ones that deserve specific humanitarian interventions. The report is a breath of fresh air coming from the human rights bodies and is a piece of much welcome advice to the international community in unprecedented times like these.

But as much as the report is politically nuanced, it falls short in delivering concrete policy interventions or strict obligations on the states to assist the conflict-ridden or low-income states. It does not take a genius to imagine the utter disregard of healthcare practices under humanitarian law or human rights law in cases of nations battling international armed conflicts between states and Non-State Armed Groups (NSAGs) amid the pandemic. Thus, in the absence of concrete obligations, the United Nations, as an international human rights body, cannot be said to be performing at its level best in the time, the world needs it the most.

The UN bodies lack a coordinating effort at this crucial time with the Security Council merely interested in building a global solidarity movement across countries. The General Assembly requires concrete decision-making in its approach. The UNGA adopted two resolutions recently in the wake of COVID-19, calling for increased participation of all countries to battle the virus together. ${ }^{50}$ While the resolutions are welcome for being politically correct, they fall short in terms of binding the member-states in obligations that would necessarily ensure global solidarity.

\section{The role of WHO}

It is worth appreciating that the role of WHO is monumental in creating awareness

49 'UNSDG, COVID-19 and Human Rights: We Are All in This Together', available at https://unsdg.un.org/ resources/covid-19-and-human-rights-we-are-all-together, accessed on 25 July 2020.

50 'UNGA Adopts Resolution on Covid-19', Livemint, 3 April 2020, available at https://www.livemint. $\mathrm{com} /$ news/world/unga-adopts-resolution-on-covid-19-calls-for-global-cooperation-to-fightpandemic-11585919363049.html, accessed on 26 July 2020. 
about this deadly virus. This international body has time and again emphasized the importance of bringing humanitarian law to the forefront in achieving universal healthcare..$^{51}$ The shift of WHO to the Alma Ata approach is principled on the idea of dismissing healthcare from an elitist concept to a socio-economic, equity-based plan. The general conception of healthcare before 1978, was always limited to hospitals and doctors. However, post-1978, 134 member states of the WHO signed the Declaration of Alma Ata that emphasized the significance of health as a socio-economic determinant. ${ }^{52}$ This declaration revamped the jurisprudence on health as human right available to all through global solidarity. ${ }^{53}$

It is worth pointing out that WHO has been consistent in following evidence-based monitoring programs in complicated settings by bridging the gap between states involved in the conflict and international organizations that engage in delivering humanitarian aid. But despite addressing essential health services, the domain of acute and chronic health issues remains largely unaddressed be it from WHO's side or any other international body. ${ }^{54}$

WHO's capabilities as an international body affiliated with the UN are thoroughly put to the test during the COVID-19 pandemic. WHO single-handedly, without the support of the other UN bodies 'has been at the heart of the battle against COVID19. ${ }^{55}$ Right from China first reporting the cluster of pneumonia cases to the WHO, to the declaration of the pandemic, WHO has acted on its toes. Amid this crisis, WHO has had to deal with its share of controversies. The U.S. President Donald Trump decided to halt payments to the WHO on the $14^{\text {th }}$ of April. ${ }^{56}$ In the wake of the soon to be held, presidential elections in the U.S.A., the WHO is marred in controversy. It is yet to be seen if the WHO gives in to the manipulation of China and the political gamble of the U.S.A.

\section{Concluding thoughts and suggestions}

It is unclear whether COVID-19 will further exaggerate armed conflicts, but it can be said for sure that this pandemic will worsen the pre-existing humanitarian crisis. It is upon the humanitarian organizations like the ICRC and the international community to act urgently in sending aid to the areas battling the humanitarian crisis.

Increasingly targeted attacks on healthcare professionals in gross violation of IHL in the past and even now, beg the attention of the international community to rethink the

\footnotetext{
51 'WHO, Placing Health at the Heart of Humanitarian Action', WHO, available at http://www.who.int/ hac/events/2015/worldhumanitariansummit_/en/, accessed on 25 July 2020.

52 Susan B Rifkin, 'Alma Ata after 40 Years: Primary Health Care and Health for All-from Consensus to Complexity,' BMJ Global Health, 2018, p. 3.

53 Ibid.

54 Gursky et al. (n 28).

55 'A Peek into WHO's Role in the Coronavirus Pandemic', Deccan Herald, 18 May 2020, available at https:// www.deccanherald.com/international/a-peek-into-whos-role-in-the-coronavirus-pandemic-838908.html, accessed on 26 July 2020.

56 Ibid.
} 
rubric of humanitarian law especially in terms of evaluating the capability and capacity of emergency healthcare. ${ }^{57}$ The ICRC should become a publicly supported entity so that nations can incorporate the study of humanitarian aid and law into the syllabus of school-going children. Students have impressionable minds, unlike imparting humanitarian values to militias in the form of a last-minute lecture that would rarely change their firm moral and ethical beliefs. ${ }^{58}$

There exists a lot of literature on the gendered impact of armed emergencies, but extremely less research on the gendered implications of public health emergencies. It is therefore essential to encourage the fieldwork of the indigenous and vulnerable populations and pave ways for them to amplify their voices through academic discourses. The urgent need of the hour is to work on healthcare in unique ways in humanitarian settings such that the needs and capabilities of women and girls are realized and put to use in ways that make them feel inclusive. ${ }^{59}$

IHL contains many provisions to ensure healthcare in humanitarian settings be it through treaty law, i.e. the Geneva Conventions or through Customary International Law. These statutory provisions require stricter implementation that can be supplemented with other relevant statutes like the Rome Statute of the International Criminal Court 60 on warcrimes to ensure that the principles and norms of IHL are respected.

The role of the International bodies is significant in light of the difficulty in holding the perpetrator accountable for war crimes. The United Nations bodies like the Security Council (UNSC) and the General Assembly (UNGA) should come up with specific implementation strategies instead of merely stating what the member-states 'ought to do.' The international community should take it upon itself to build global solidarity to mitigate the adverse effects of the COVID-19 pandemic. International organizations should be willing to negotiate with states and NSAGs to ensure humanitarian assistance in highly complex conflict zones. Better negotiation would require an evidence-based approach to build trust between the states, NSAGs and the organizations involved in humanitarian aid. ${ }^{61}$

Lastly, in devising and deciding mitigating measures for COVID-19 in humanitarian settings, the Global North should be mindful of the needs and complexities of the Global South in terms of availability of and access to, existing and buildable healthcare infrastructure.

57 Frederick Burkle et al., 'Health Care Providers in War and Armed Conflict: Operational and Educational Challenges in International Humanitarian Law and the Geneva Conventions, Part I. Historical Perspective,' Disaster Medicine and Public Health Preparedness 1, 2018, p. 13.

58 Ibid.

59 Sarah Fuhrman et al., 'Gendered Implications of the COVID-19 Pandemic for Policies and Programmes in Humanitarian Settings,' BMJ Global health, 2020, p. 5.

60 See Article 8 (2) (a) (iii), 'Rome Statute of the International Criminal Court, 1998' available at https://legal. un.org/icc/statute/99_corr/cstatute.htm, accessed on 26 July 2020.

61 'COVID-19 Symposium: COVID-19 in Conflict-Affected Areas-Armed Groups as Part of a Global Solution’ (n 40). 